\title{
Knowledge of students of selected universities about expanding professional competence of nurses and midwives with reference to prescribing medicines, writing out prescriptions, and referring for diagnostic tests
}

\begin{abstract}
Introduction. Since January $1^{\text {st }}, 2016$, particular groups of nurses and midwives in Poland are allowed to write prescriptions and refer patients to diagnostic procedures without doctors' involvement.

Aim. The aim of the study was to assess what university students know about the changes that expanded the professional competencies of nurses and midwives.

Material and methods. The study group comprised of 535 students of three different universities. The group was $82 \%$ female and the mean age was 23 years (min. $=19 ; \max .=58, \mathrm{SD}=4.780$ ). Nursing students were the largest group among the study participants (177 individuals which meant 33\% of the total), followed by Medicine students (145 individuals, 27\% of all), Midwifery (107 persons, $20 \%$ of the total), and Public Health (100 persons, 19\% of all). As many as 324 respondents (60\%) had never participated in any medical law-related courses. A voluntary and anonymous survey containing 39 questions divided into 3 parts: 13 questions about knowledge, 26 statements concerning attitudes using a Likert scale, 8 demographic questions) was used. Obtaining an approval from the University's Ethical Review Board was not required. Pearson's chi-square test was used to compare frequency of the correct answers by students of every major. The Kruskal-Wallis rank test with a post-hoc analysis for multiple comparison of mean rank sums, STATISTICA version 12.5 (StatSoft, Inc.), licensed to MUW, $\alpha=0.05$, were used to calculate the differences in summative points for correct answers.

Results. Nursing students were significantly more likely to choose the correct answers, unlike Medicine or Public Health students $(\mathrm{p}<0.001)$, as well as Midwifery students $(\mathrm{p}<0.002)$. The answers provided by the students of Medicine, Public Health, and Midwifery were relatively similar.

Conclusions. The knowledge of students of various Polish universities concerning the expansion of professional competencies of nurses and midwives was insufficient and needs to be urgently updated. Learning curricula to be modified not only for students of Nursing and Midwifery but also for other members of therapy team, e.g. physicians and pharmacists as well as specialists in public health.
\end{abstract}

Keywords: professional competence, expanding competence, students, health sciences.

DOI: $10.1515 /$ pjph-2016-0017

\section{INTRODUCTION}

Since January $1^{\text {st }} 2016$, certain groups of nurses and midwives in Poland are allowed to write prescriptions under medical order, prescribe certain medication, including writing prescriptions for these drugs, as well as referring patients to diagnostic tests on their own, excluding high-risk methods (hereinafter referred to as expanding the powers of nurses and midwives - EPN\&M), without doctors' involvement $[1,2]$.

These changes were introduced under the amendment to the Nurses and Midwives Act [1,2] and constitute one of the elements introducing the model of Advanced Nurse Practitioner in Poland [3]. However, they are rights, not duties [4-10]. Still, the scope of competencies is dependent on one's level of education (whether Bachelor or Master) and completed forms of postgraduate training (specialist course, specialized training) in the field of nursing and midwifery [1,2,4-10].

Nursing and Midwifery students entering universities in the academic year 2015-16 are the group who should gain new powers defined in the Act and they do not need to receive any additional postgraduate training. Study schedules for these faculties were modified at the beginning of the 2015-16 academic year which means that the content concerning the discussed professional qualifications has already been included in the study programs and learning material for particular courses.

However, due to the fact that EPN\&M should not only affect nurses or midwives but also doctors and a group of public health professionals indirectly, in the wider sense, students of all subjects related to medicine should gain basic knowledge of EPN\&M.

\footnotetext{
${ }^{1}$ Division of Teaching and Outcomes of Education, Faculty of Health Science, Medical University of Warsaw, Poland

${ }^{2}$ Student Research Society for Medical Law, Warsaw Medical University, Poland

${ }^{3}$ Collegium Masovienese, Żyrardów, Poland
} 


\section{AIM}

The authors looked to check the knowledge of university students about extending professional competence of nurses and midwives with special attention paid to prescribing medicines, writing out prescriptions and referring to diagnostic tests among students of selected universities.

\section{MATERIAL AND METHODS}

The authors looked at a group consisting of 535 individuals, all students of selected medical universities in Poland. Some 417 (78\%) of them were students of Medical University of Warsaw, 104 students (19\%) of Ludwik Rydygier Collegium Medicum in Bydgoszcz, and 14 students (3\%) of Józef Piłsudski University of Physical Education in Warsaw. Questionnaire return rate reached $41 \%$.

As many as 439 women ( $82 \%$ of the total) and 92 men (17\% of all) participated in the study. Four individuals $(1 \%)$ provided no gender information. The mean age of the study group was 23 years $(\min .=19 ; \max .=58, \mathrm{SD}=4.780$, median $=23$, mode $=22$ ).

Nursing students constituted the largest subgroup among the study participants (177 persons, 33\% of all), followed by Medicine students (145 persons, 27\%), Midwifery (107 persons, $20 \%$ ), and Public Health (100 persons, 19\%). 6 participants $(1 \%)$ provided no answer about their studies.

Bachelor's degree students constituted the largest subgroup among the study participants (288 individuals, which means 54\%) (majors: Nursing, Midwifery, and Public Health). There were 151 students (28\%) of a one-cycle Master's degree programme in Medicine and 82 students $(15 \%)$ of a second-cycle degree programme. 14 persons $(3 \%)$ did not provide any information on this issue.

The study group was mostly composed of first-year students (218 persons, 41\%), followed by second-year students (135 persons, 25\%), fourth-year students (57 persons, 11\%), third-year students (53 persons, 10\%), and fifth-year students (44 persons, 8\%). Sixth-year students constituted the smallest subgroup among the study participants (20 persons, $4 \%$ ). 8 persons $(2 \%)$ provided no information about their education. .

Some 324 respondents $(60 \%)$ have never acquainted themselves with medical law and $208(39 \%)$ said that they had already taken a course in medical law. Also, 3 individuals (1\%) did not provide such information.

Additionally, some 409 participants (76\%) had neither graduated from any other major nor studied another major at the same time. Some 83 respondents $(16 \%)$ were students of another major and 37 individuals $(7 \%)$ had graduated from another major before. Also, 6 individuals $(1 \%)$ provided no answer to that question.

\section{METHODS}

In a voluntary and anonymous survey conducted between May and June 2015, the authors used an original questionnaire. Its validity was tested at the Division of Teaching and Outcomes of Education, Faculty of Health Science, Warsaw Medical University, which revealed that it was a reliable research tool that might be used for analyzing students' knowledge and attitudes toward extending professional competence of nurses and midwives [11].
The questionnaire consisted of three parts and comprised a total of 39 questions. The first part consisted of questions checking students' knowledge about extending professional competence of nurses and midwives. There were 13 close-ended questions: 6 questions with 5 answer options, 5 questions with 4 answer options, including one correct answer and an "I don't know" answer option, and 2 questions with 3 answer options.

The second part of the questionnaire comprised of questions concerning the students' attitudes toward the issue and it consisted of 18 statements on extending professional competence. Attitudes toward the statements were assessed by the study group using a Likert scale ( 1 - strongly disagree, 3 - no opinion, 5 - strongly agree). The third part of the questionnaire focused on socio-demographic data about the study group and comprised 8 questions about gender, age, major, year and mode of studies, concurrent studies, taking up employment in a certain profession and the present experience of learning medical law.

\section{Ethical Review Board}

The authors of the present study did not apply for approval of the Ethical Review Board of Warsaw Medical University for this study. This was due to the fact that, according to the statement issued by the Ethical Review Board of MUW : "The Ethical Review Board do not give any opinion on surveys, retrospective, and other non-invasive studies" [12].

\section{Statistical analysis of the study results}

Pearson's non-parametric chi-square test was used to compare the frequency of correct answers to questions about knowledge by the major. On the other hand, the Kruskal-Wallis rank test with a post-hoc analysis for multiple comparison of mean rank sums was used to calculate potential differences in summative points for correct answers provided by students of different majors. STATISTICA statistical package version 12.5 (StatSoft, Inc.) licensed to MUW was used in the analysis. The a priori significance level was established for all analyses at $\alpha=0.05$.

\section{RESULTS}

Over one-third of the study group (39\%) provided a correct answer to the question concerning the legal act introducing the amendments extending professional competence of nurses and midwives in the field of prescribing medicine, writing out prescriptions and referring patients to diagnostic tests. A similarly large group of the respondents (35\%) failed to provide any answer. A half of the Nursing students (53\%) and nearly a half of the Midwifery students (46\%) pointed to the correct answer. See Table 1 for detailed information.

Almost one third of the study participants (29\%) were able to point to the effective date of the amendments concerning the new powers of nurses and midwives. Nearly a half of the Nursing students (42\%) and less than one-fourth of Midwifery students selected the correct answer $(21 \%)$. See Table 2 for more detailed information.

Half of the study participants (51\%) were aware that the new competencies that nurses and midwives received are their rights, not duties. Among the group directly interested in new changes, the correct answer was provided by a large majority of Nursing students $(70 \%)$ and almost a half of the Midwifery students (43\%). See Table 3 for more detailed information. 
A question about the students' knowledge of particular groups of nurses and midwives demonstrated that the respondents did not know the particular provisions about prescribing medication and writing prescriptions on their own, without doctors' involvement (Table 4), prolonging medical orders for certain medication and writing out prescriptions for these drugs (Table 5), as well as referring patients for diagnostic tests (Table 6) by nurses and midwives. Students of Nursing and Midwifery provided answers that were similar to those given by the entire group of the study participants.

Nearly a half of the study group knew that the laws regulating the subject of referring patients to diagnostic tests shall be limited and a detailed list of the tests should be provided in a regulation (49\%). Over a half of Nursing students $(63 \%)$ and almost a half of Midwifery students (41\%) gave the correct answer. See Table 7 for detailed data.

Less than a one-fourth of the respondents (24\%) knew that these new regulations should not only affect prescribing medicines but also the food that is intended for particular nutritional uses and medical devices. Less than a half of the students (41\%) did not provide any answer to the question. The Nursing and Midwifery students, despite being the most affected subgroups, responded to the question similarly to the entire group of the study participants. See Table 8 for more details.

TABLE 1. Students' knowledge of legal acts amended to introduce new professional qualifications for nurses and midwives.

\begin{tabular}{|c|c|c|c|c|c|c|}
\hline & Question & 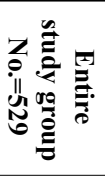 & 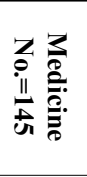 & 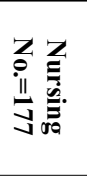 & 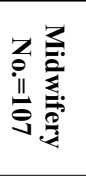 & 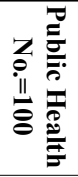 \\
\hline \multirow{5}{*}{$\begin{array}{l}\text { Which of the following Acts } \\
\text { was amended to broaden the scope of } \\
\text { nurses and midwives qualifications } \\
\text { in prescribing medication } \\
\text { and writing prescriptions } \\
\text { without doctors' involvement: }\end{array}$} & $\begin{array}{l}\text { The Act of May 12, } 2011 \mathrm{r} \text {. on the Reimbursement of Medicines, } \\
\text { Foodstuffs Intended for Particular Nutritional Uses and Medical Devices }\end{array}$ & $\begin{array}{c}44 \\
(8 \%)\end{array}$ & $\begin{array}{c}9 \\
(6 \%)\end{array}$ & $\begin{array}{l}13 \\
(7 \%)\end{array}$ & $\begin{array}{c}11 \\
(10 \%)\end{array}$ & $\begin{array}{c}11 \\
(11 \%)\end{array}$ \\
\hline & Nurses and Midwives Act of July 15, 2011 & $\begin{array}{c}210 \\
(39 \%)\end{array}$ & $\begin{array}{c}22 \\
(15 \%)\end{array}$ & $\begin{array}{c}93 \\
(53 \%)\end{array}$ & $\begin{array}{c}49 \\
(46 \%)\end{array}$ & $\begin{array}{c}40 \\
(40 \%)\end{array}$ \\
\hline & $\begin{array}{l}\text { Act of July 1, } 2011 \text { on Professional Self-Government of Nurses } \\
\text { and Midwives }\end{array}$ & $\begin{array}{c}44 \\
(8 \%)\end{array}$ & $\begin{array}{c}3 \\
(2 \%)\end{array}$ & $\begin{array}{c}30 \\
(17 \%)\end{array}$ & $\begin{array}{c}10 \\
(9 \%)\end{array}$ & $\begin{array}{c}1 \\
(1 \%)\end{array}$ \\
\hline & Nurses and Midwives Act of July 5, 1996. & $\begin{array}{c}45 \\
(8 \%)\end{array}$ & $\begin{array}{c}15 \\
(10 \%)\end{array}$ & $\begin{array}{c}8 \\
(5 \%)\end{array}$ & $\begin{array}{c}7 \\
(7 \%)\end{array}$ & $\begin{array}{c}15 \\
(15 \%)\end{array}$ \\
\hline & I do not know & $\begin{array}{c}186 \\
(35 \%)\end{array}$ & $\begin{array}{c}95 \\
(66 \%)\end{array}$ & $\begin{array}{c}31 \\
(18 \%)\end{array}$ & $\begin{array}{c}27 \\
(25 \%)\end{array}$ & $\begin{array}{c}33 \\
(33 \%)\end{array}$ \\
\hline
\end{tabular}

TABLE 2. Students' knowledge about the effective date of amendments introducing new responsibilities of nurses and midwives.

\begin{tabular}{|c|c|c|c|c|c|c|}
\hline Question & & 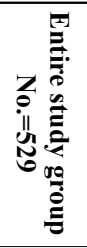 & 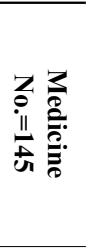 & 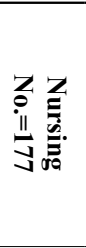 & 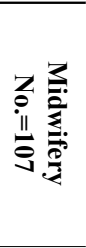 & 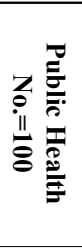 \\
\hline \multirow{5}{*}{$\begin{array}{l}\text { When would the chang- } \\
\text { es expanding nurses } \\
\text { and midwives } \\
\text { professional } \\
\text { qualifications } \\
\text { to prescribe certain } \\
\text { medication and write } \\
\text { prescriptions without } \\
\text { doctors' involvement } \\
\text { come into force? }\end{array}$} & $\begin{array}{c}\text { July 1, } \\
2017 \\
\end{array}$ & $\begin{array}{c}18 \\
(3 \%)\end{array}$ & $\begin{array}{c}1 \\
(1 \%) \\
\end{array}$ & $\begin{array}{c}2 \\
(1 \%) \\
\end{array}$ & $\begin{array}{c}10 \\
(9 \%) \\
\end{array}$ & $\begin{array}{c}5 \\
(5 \%)\end{array}$ \\
\hline & $\begin{array}{c}\text { January 1, } \\
2017 \\
\end{array}$ & $\begin{array}{c}67 \\
(13 \%) \\
\end{array}$ & $\begin{array}{c}15 \\
(10 \%)\end{array}$ & $\begin{array}{c}19 \\
(11 \%)\end{array}$ & $\begin{array}{c}19 \\
(18 \%)\end{array}$ & $\begin{array}{c}13 \\
(13 \%)\end{array}$ \\
\hline & $\begin{array}{c}\text { July } 1 \text {, } \\
2016\end{array}$ & $\begin{array}{c}84 \\
(16 \%) \\
\end{array}$ & $\begin{array}{c}4 \\
(3 \%) \\
\end{array}$ & $\begin{array}{c}45 \\
(25 \%) \\
\end{array}$ & $\begin{array}{c}23 \\
(21 \%) \\
\end{array}$ & $\begin{array}{c}11 \\
(11 \%)\end{array}$ \\
\hline & $\begin{array}{c}\text { January } 1, \\
2016\end{array}$ & $\begin{array}{c}157 \\
(29 \%)\end{array}$ & $\begin{array}{c}42 \\
(29 \%)\end{array}$ & $\begin{array}{c}75 \\
(42 \%)\end{array}$ & $\begin{array}{c}22 \\
(21 \%)\end{array}$ & $\begin{array}{c}15 \\
(15 \%)\end{array}$ \\
\hline & $\begin{array}{l}\text { I do not } \\
\text { know. }\end{array}$ & $\begin{array}{c}207 \\
(39 \%)\end{array}$ & $\begin{array}{c}82 \\
(57 \%)\end{array}$ & $\begin{array}{c}36 \\
(20 \%)\end{array}$ & $\begin{array}{c}32 \\
(30 \%)\end{array}$ & $\begin{array}{c}56 \\
(56 \%)\end{array}$ \\
\hline
\end{tabular}

TABLE 3. Students' knowledge of whether the new competencies of nurses and midwives are rights or duties.

\begin{tabular}{|c|c|c|c|c|c|c|}
\hline Question & & 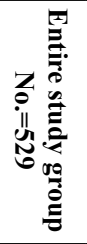 & 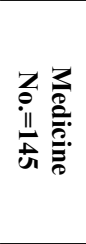 & 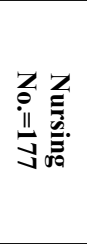 & 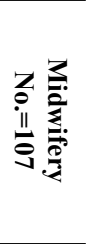 & 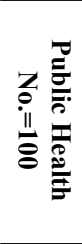 \\
\hline \multirow{3}{*}{$\begin{array}{l}\text { Will prescribing } \\
\text { certain medicines } \\
\text { and writing prescrip- } \\
\text { tions without doctors' } \\
\text { involvement be nurses } \\
\text { and midwives' duties: }\end{array}$} & Yes & $\begin{array}{c}127 \\
(24 \%) \\
\end{array}$ & $\begin{array}{c}21 \\
(14 \%)\end{array}$ & $\begin{array}{c}34 \\
(19 \%) \\
\end{array}$ & $\begin{array}{c}36 \\
(34 \%) \\
\end{array}$ & $\begin{array}{c}35 \\
(35 \%)\end{array}$ \\
\hline & No & $\begin{array}{c}273 \\
(51 \%)\end{array}$ & $\begin{array}{c}63 \\
(43 \%)\end{array}$ & $\begin{array}{c}124 \\
(70 \%)\end{array}$ & $\begin{array}{c}46 \\
(43 \%)\end{array}$ & $\begin{array}{c}36 \\
(36 \%)\end{array}$ \\
\hline & $\begin{array}{l}\text { I do not } \\
\text { know }\end{array}$ & $\begin{array}{c}131 \\
(24 \%)\end{array}$ & $\begin{array}{c}59 \\
(41 \%)\end{array}$ & $\begin{array}{c}17 \\
(10 \%)\end{array}$ & $\begin{array}{c}25 \\
(23 \%)\end{array}$ & $\begin{array}{c}29 \\
(29 \%)\end{array}$ \\
\hline
\end{tabular}

TABLE 4. Students' knowledge of particular groups of nurses and midwives capable of prescribing certain medicines and writing out prescriptions independently.

\begin{tabular}{llcccc}
\hline & & & & & \\
\end{tabular}


Half of the study group (50\%) knew that the scope of nurses and midwives' qualifications specified in the Act is dependent on their level of education. The Nursing and Midwifery students also responded to this question in a similar fashion as the rest of the study group did. See Table 9 for more detailed information.

Less than one-third of the respondents (30\%) were able to mention the legal act specifying the list of medicines that nurses and midwives should be capable of prescribing on their own. Almost a half of the Nursing students (45\%) and less than one-fourth of the Midwifery students (22\%) knew the correct answer. See Table 10 for detailed data.

The respondents did not know the forms of education that, due to their new powers, would entitle nurses and midwives to prescribe medication (Table 11), prolong prescriptions for medicines ordered earlier by doctors (Table 12), as well as refer patients for selected diagnostic tests without doctors' involvement (Table 13). Nearly one-third of the study group provided the correct answer. The Nursing and Midwifery students responded similarly to the rest of the study group

An analysis of easiness of particular questions about the knowledge of new professional powers of nurses and midwives demonstrated that the questions were difficult for the students.

Students of different majors provided varied answers with statistically significant differences. $(p<0.000)$ (Table 15) (Figure 1). The students of Nursing were far more likely to choose the correct answers than either Medicine or Public Health students $(\mathrm{p}<0.001)$ and students of Midwifery $(\mathrm{p}<0.002)$ (Table 16). The answers provided by the students of Medicine, Public Health, and Midwifery did not differ significantly (Table 16).

\section{DISCUSSION}

The available literature (PubMed, SCOPUS, ProQuest, key words: nurse prescribing, years: 2000-2015) consists as many as 65 publications on prescribing medicines by nurses and midwives in numerous European and countries around the world. The issue has been broadly discussed by various authors, presenting various experiences on the country level concerning the competencies for prescribing medicine by nursers and midwives: problems associated with new laws, attitudes of healthcare staff toward these rights and economic analyses [13-19]. A few publications focused on the knowledge of and attitudes toward these rights among Nursing and Midwifery students.

No Polish author has ever touched upon the very subject before (the authors looked through Polish Medical Bibliography, key words: nurses AND prescriptions, years: 2000-2015). Many articles in the available literature devoted to EPN\&M have been published in the trade press rather than in scientific literature [20-27]. They focused mainly on the scope of powers and the required qualifications of nurses and midwives and they did not present any study results concerning knowledge of and attitudes towards new powers of nurses and midwives among selected groups of healthcare professionals.

Authors of the present study were the only Polish researchers dealing with the issue and providing topic-specific literature in Polish [1-6].

The issues of prescribing medication, writing prescriptions and referring to diagnostic tests by nurses and midwives constitute a new topic in the Polish scientific literature and a very up-to-date one due to the ongoing preparations for the implementation of changes in law beginning on January 1st, 2016. Previous studies by the authors of this study focusing on this issue analyzed the attitudes of departmental [2] and divisional nurses, employees of a children's teaching hospital [5]. A study involving students was just a pilot qualitative focus study conducted among a not numerous group of students participating in medical law workshops $[1,6]$.

Previous studies carried out among students of majors other than Nursing and Midwifery were conducted at the Medical University of Warsaw just as a pilot [10].

Studies conducted among other groups of students, like Medicine or Public Health of different universities have not been performed yet, thus the present authors decided to include in the study also these groups that are not directly involved in the new competencies.

The level of knowledge of expanding the powers of nurses and midwives with respect to prescribing medicines, writing prescriptions, and referring for diagnostic tests was clearly insufficient among the study group of students of Nursing and Midwifery as well as of Public Health and Medicine of selected Polish medical universities. The Nursing students had significantly better knowledge than students of any other major but it was still unsatisfactory. The level of knowledge of the Nursing students was significantly better mainly with respect to the basic issues related to the new powers.

Over a half of the Nursing students were able to mention the legal act that introduces the most important changes concerning the new powers, a vast majority of them (70\%) knew that the powers shall constitute their rights and not duties, but only $42 \%$ of them knew when the changes enter into force.

Regardless of the major, the students were not familiar with the remaining issues covering the detailed knowledge of the new powers of nurses and midwives. Most students did not know what will make the powers of nurses and midwives with a Bachelor's and Master's degree different and which forms of postgraduate education will be required to exercise the extended powers in practice.

The authors of the present study believe that the results are not surprising due to the fact that an informational campaign on the new professional competencies conducted among professionally active nurses and midwives was insufficient and students did not receive any information devoted particularly to them either, even though they will be able to exercise these powers after graduation. However, it is surprising that the Midwifery students had a significantly lower level of knowledge

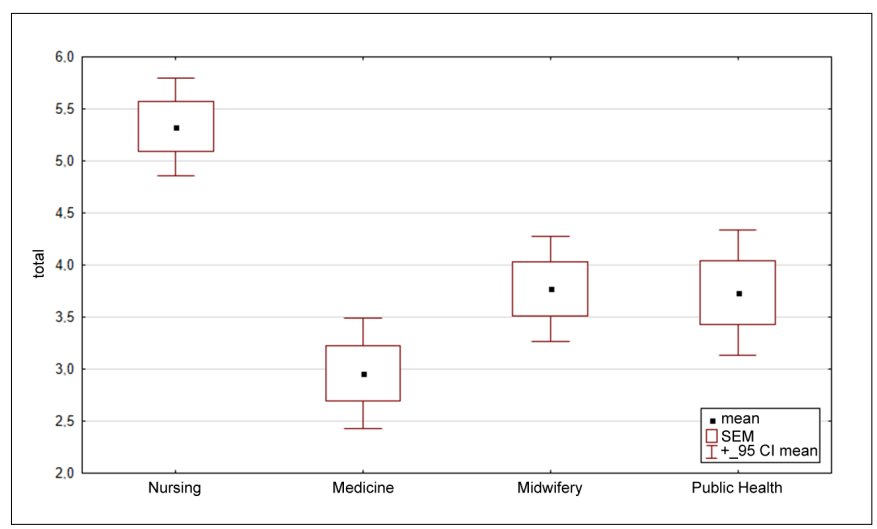

FIGURE 1. Analysis of correct answers provided by students of different majors to questions about knowledge of new professional powers of nurses and midwives. 
TABLE 5. Students' knowledge of groups of nurses and midwives capable of prolonging medical orders for certain medicines and writing out prescriptions for these drugs on their own.

Will each nurse and midwife be able to "prolong" certain medicines and write out prescriptions for these drugs?

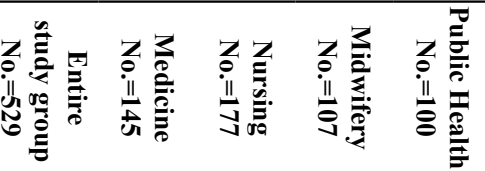

Question

Yes, each nurse and midwife

Only nurses and midwives holding a Bachelor's degree

Only nurses and midwives holding a Bachelor's degree

who graduated from a specialised training in this field as well

Only nurses and midwives with a Bachelor's degree who graduated

from a specialised training in this field as well and nurses and midwives with the right to prescribe medicines

\section{I do not know.}

\begin{tabular}{ccccc}
65 & 5 & 30 & 17 & 12 \\
$(12 \%)$ & $(3 \%)$ & $(17 \%)$ & $(16 \%)$ & $(12 \%)$ \\
\hline 28 & 5 & 7 & 9 & 6 \\
$(5 \%)$ & $(3 \%)$ & $(4 \%)$ & $(8 \%)$ & $(6 \%)$ \\
\hline 98 & 18 & 45 & 18 & 16 \\
$(18 \%)$ & $(12 \%)$ & $(25 \%)$ & $(17 \%)$ & $(16 \%)$ \\
147 & 32 & 55 & 33 & 27 \\
$(27 \%)$ & $(22 \%)$ & $(31 \%)$ & $(31 \%)$ & $(27 \%)$ \\
188 & 82 & 36 & 30 & 38 \\
$(35 \%)$ & $(57 \%)$ & $(20 \%)$ & $(28 \%)$ & $(38 \%)$ \\
\hline
\end{tabular}

TABLE 6. Students' knowledge of groups of nurses and midwives capable of referring patients for diagnostic tests independently.

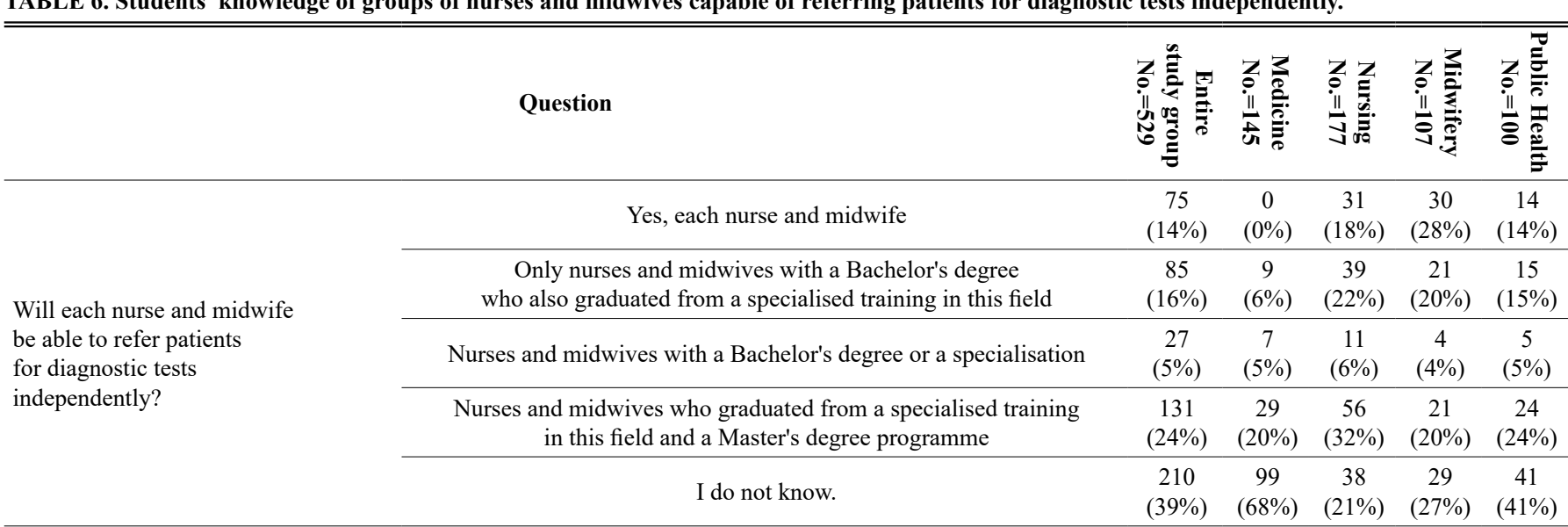

TABLE 7. Students' knowledge of powers of nurses and midwives with respect to referring patients for diagnostic tests.

\begin{tabular}{|c|c|c|c|c|c|c|}
\hline & Question & 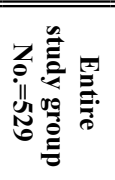 & 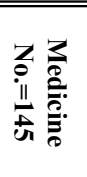 & 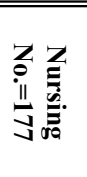 & Z & 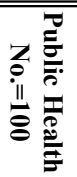 \\
\hline \multirow{4}{*}{$\begin{array}{l}\text { Will the nurses and midwives' } \\
\text { power to refer patients } \\
\text { for diagnostic tests be limited? }\end{array}$} & $\begin{array}{l}\text { No, nurses and midwives will be able to refer patients } \\
\text { for any diagnostic tests }\end{array}$ & $\begin{array}{c}37 \\
(7 \%)\end{array}$ & $\begin{array}{c}3 \\
(2 \%)\end{array}$ & $\begin{array}{c}9 \\
(5 \%)\end{array}$ & $\begin{array}{c}16 \\
(15 \%)\end{array}$ & $\begin{array}{c}9 \\
(9 \%)\end{array}$ \\
\hline & $\begin{array}{l}\text { Yes, nurses and midwives will be able to refer patients } \\
\text { for diagnostic tests except for laboratory diagnosis }\end{array}$ & $\begin{array}{c}46 \\
(9 \%)\end{array}$ & $\begin{array}{c}3 \\
(2 \%)\end{array}$ & $\begin{array}{c}23 \\
(13 \%)\end{array}$ & $\begin{array}{c}12 \\
(11 \%)\end{array}$ & $\begin{array}{c}8 \\
(8 \%)\end{array}$ \\
\hline & $\begin{array}{l}\text { Yes, nurses and midwives will be able to refer patients only } \\
\text { for those diagnostic tests that are specified by a regulation }\end{array}$ & $\begin{array}{c}260 \\
(49 \%)\end{array}$ & $\begin{array}{c}58 \\
(40 \%)\end{array}$ & $\begin{array}{c}112 \\
(63 \%)\end{array}$ & $\begin{array}{c}44 \\
(41 \%)\end{array}$ & $\begin{array}{c}43 \\
(43 \%)\end{array}$ \\
\hline & I do not know. & $\begin{array}{c}184 \\
(34 \%)\end{array}$ & $\begin{array}{c}77 \\
(53 \%)\end{array}$ & $\begin{array}{c}31 \\
(18 \%)\end{array}$ & $\begin{array}{c}35 \\
(33 \%)\end{array}$ & $\begin{array}{c}39 \\
(39 \%)\end{array}$ \\
\hline
\end{tabular}

TABLE 8. Students' knowledge of group of medicines to be covered by extended powers of nurses and midwives.

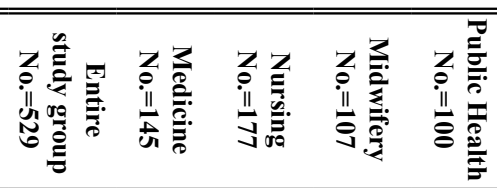

\begin{tabular}{|c|c|c|c|c|c|c|}
\hline & & & & & & \\
\hline \multirow{5}{*}{$\begin{array}{l}\text { The changes in extending nurses } \\
\text { and midwives' professional } \\
\text { competencies would affect }\end{array}$} & Prescribing OTC drugs & $\begin{array}{c}39 \\
(7 \%)\end{array}$ & $\begin{array}{c}3 \\
(2 \%)\end{array}$ & $\begin{array}{c}9 \\
(5 \%)\end{array}$ & $\begin{array}{c}16 \\
(15 \%)\end{array}$ & $\begin{array}{c}11 \\
(11 \%)\end{array}$ \\
\hline & Prescribing reimbursed drugs & $\begin{array}{c}45 \\
(8 \%)\end{array}$ & $\begin{array}{c}10 \\
(7 \%)\end{array}$ & $\begin{array}{c}18 \\
(10 \%)\end{array}$ & $\begin{array}{c}10 \\
(9 \%)\end{array}$ & $\begin{array}{c}6 \\
(6 \%)\end{array}$ \\
\hline & $\begin{array}{l}\text { Prescribing medication, foodstuffs intended } \\
\text { for particular nutritional uses and medical devices }\end{array}$ & $\begin{array}{c}128 \\
(24 \%)\end{array}$ & $\begin{array}{c}32 \\
(22 \%)\end{array}$ & $\begin{array}{c}56 \\
(32 \%)\end{array}$ & $\begin{array}{c}20 \\
(19 \%)\end{array}$ & $\begin{array}{c}20 \\
(20 \%)\end{array}$ \\
\hline & Prescribing medication and medical devices on medical order & $\begin{array}{c}96 \\
(18 \%) \\
\end{array}$ & $\begin{array}{c}18 \\
(12 \%) \\
\end{array}$ & $\begin{array}{c}45 \\
(25 \%) \\
\end{array}$ & $\begin{array}{c}12 \\
(11 \%)\end{array}$ & $\begin{array}{c}18 \\
(18 \%) \\
\end{array}$ \\
\hline & I do not know & $\begin{array}{c}221 \\
(41 \%)\end{array}$ & $\begin{array}{c}80 \\
(55 \%)\end{array}$ & $\begin{array}{c}48 \\
(27 \%)\end{array}$ & $\begin{array}{c}48 \\
(45 \%)\end{array}$ & $\begin{array}{c}44 \\
(44 \%)\end{array}$ \\
\hline
\end{tabular}


TABLE 9. Knowledge of students of selected universities about extending professional competence of nurses and midwives with reference to prescribing medicines, writing out prescriptions, and referring for diagnostic tests.

\begin{tabular}{|c|c|c|c|c|c|c|}
\hline Question & & 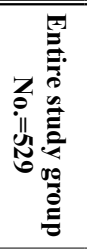 & 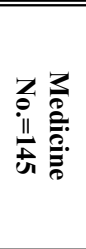 & 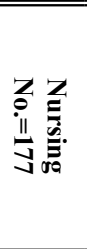 & 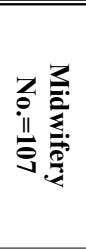 & 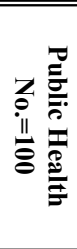 \\
\hline \multirow{3}{*}{$\begin{array}{l}\text { Nurses and midwives } \\
\text { holding a Bachelor's } \\
\text { or a Master's degree } \\
\text { should receive different } \\
\text { professional competencies, } \\
\text { particularly when it comes } \\
\text { to prescribing certain } \\
\text { medication and writing } \\
\text { prescriptions without } \\
\text { doctors' involvement. }\end{array}$} & Yes & $\begin{array}{c}270 \\
(50 \%)\end{array}$ & $\begin{array}{c}63 \\
(43 \%)\end{array}$ & $\begin{array}{c}105 \\
(59 \%)\end{array}$ & $\begin{array}{c}48 \\
(45 \%)\end{array}$ & $\begin{array}{c}51 \\
(51 \%)\end{array}$ \\
\hline & No & $\begin{array}{c}79 \\
(15 \%)\end{array}$ & $\begin{array}{c}7 \\
(5 \%)\end{array}$ & $\begin{array}{c}33 \\
(19 \%)\end{array}$ & $\begin{array}{c}23 \\
(21 \%)\end{array}$ & $\begin{array}{c}15 \\
(15 \%)\end{array}$ \\
\hline & $\begin{array}{l}\text { I do not } \\
\text { know }\end{array}$ & $\begin{array}{c}183 \\
(34 \%)\end{array}$ & $\begin{array}{c}74 \\
(51 \%)\end{array}$ & $\begin{array}{c}38 \\
(21 \%)\end{array}$ & $\begin{array}{c}36 \\
(34 \%)\end{array}$ & $\begin{array}{c}34 \\
(34 \%)\end{array}$ \\
\hline
\end{tabular}

of the new professional powers compared to the Nursing students. These findings need to be looked into further. However, particular attention should be paid to the learning curriculum for Midwifery students which is supposed to enrich the students' knowledge of the new regulations.

With the new professional competencies of nurses and midwives entering into force, teaching standards for these majors will soon be modified. The curricula for Bachelor's degree programs in Nursing and Midwifery will also be adjusted to the new teaching standards issued by the Ministry of Science and Higher Education. The authors of this study believe that it is necessary to modify and complement the learning curricula with new competencies of nurses and midwives not only for Nursing and Midwifery students but for other medical majors as well. According to the authors of this study, all interdisciplinary team members, including doctors and pharmacists in particular, should be aware of the new competencies since they will be directly involved in the execution of these powers.

TABLE 10. Students' knowledge of the legal act in which a list of medicines that nurses and midwives shall be entitled to prescribe on their own will be published.

\begin{tabular}{|c|c|c|c|c|c|c|}
\hline & Question & 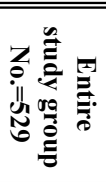 & 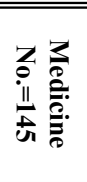 & 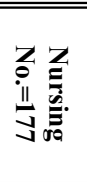 & 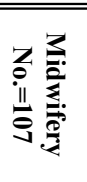 & 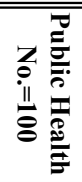 \\
\hline \multirow{4}{*}{$\begin{array}{l}\text { A list of medicines that nurses } \\
\text { and midwives shall be entitled } \\
\text { to prescribe on their own } \\
\text { and write out prescriptions } \\
\text { for these drugs will be published in: }\end{array}$} & Regulation of the Minister of Health & $\begin{array}{c}163 \\
(30 \%)\end{array}$ & $\begin{array}{c}27 \\
(19 \%)\end{array}$ & $\begin{array}{c}79 \\
(45 \%)\end{array}$ & $\begin{array}{c}24 \\
(22 \%)\end{array}$ & $\begin{array}{c}31 \\
(31 \%)\end{array}$ \\
\hline & The new Nurses and Midwives Act & $\begin{array}{c}61 \\
(11 \%)\end{array}$ & $\begin{array}{c}9 \\
(6 \%)\end{array}$ & $\begin{array}{c}27 \\
(15 \%)\end{array}$ & $\begin{array}{c}12 \\
(11 \%)\end{array}$ & $\begin{array}{c}12 \\
(12 \%)\end{array}$ \\
\hline & Act amending the Nurses and Midwives Act & $\begin{array}{c}108 \\
(20 \%)\end{array}$ & $\begin{array}{c}23 \\
(16 \%)\end{array}$ & $\begin{array}{c}35 \\
(20 \%)\end{array}$ & $\begin{array}{c}28 \\
(26 \%)\end{array}$ & $\begin{array}{c}20 \\
(20 \%)\end{array}$ \\
\hline & I do not know & $\begin{array}{c}198 \\
(37 \%)\end{array}$ & $\begin{array}{c}83 \\
(57 \%)\end{array}$ & $\begin{array}{c}35 \\
(20 \%)\end{array}$ & $\begin{array}{c}43 \\
(40 \%)\end{array}$ & $\begin{array}{c}37 \\
(37 \%)\end{array}$ \\
\hline
\end{tabular}

TABLE 11. Students' knowledge of forms of education that, in accordance with new legal arrangements, shall entitle nurses and midwives to prescribe certain medicines independently.

Please indicate which of the following forms of education shall, in accordance with the new legal arrangements, entitle nurses and midwives to prescribe certain medicines independently:
Question

\begin{tabular}{|c|c|c|c|c|c|}
\hline $\begin{array}{l}\text { "Specialisation" and/or graduation from a Master's } \\
\text { degree programme and a specialized training }\end{array}$ & $\begin{array}{c}156 \\
(29 \%)\end{array}$ & $\begin{array}{c}33 \\
(23 \%)\end{array}$ & $\begin{array}{c}70 \\
(40 \%)\end{array}$ & $\begin{array}{c}25 \\
(23 \%)\end{array}$ & $\begin{array}{c}26 \\
(26 \%)\end{array}$ \\
\hline Both a specialization and a specialized training & $\begin{array}{c}46 \\
(9 \%)\end{array}$ & $\begin{array}{c}6 \\
(4 \%)\end{array}$ & $\begin{array}{c}20 \\
(11 \%)\end{array}$ & $\begin{array}{c}12 \\
(11 \%)\end{array}$ & $\begin{array}{c}8 \\
(8 \%)\end{array}$ \\
\hline $\begin{array}{l}\text { Graduation from a Master's degree programme } \\
\text { and a specialized training }\end{array}$ & $\begin{array}{c}120 \\
(22 \%)\end{array}$ & $\begin{array}{c}24 \\
(17 \%)\end{array}$ & $\begin{array}{c}51 \\
(29 \%)\end{array}$ & $\begin{array}{c}27 \\
(25 \%)\end{array}$ & $\begin{array}{c}17 \\
(17 \%)\end{array}$ \\
\hline I do not know & $\begin{array}{c}205 \\
(38 \%)\end{array}$ & $\begin{array}{c}80 \\
(55 \%)\end{array}$ & $\begin{array}{c}32 \\
(18 \%)\end{array}$ & $\begin{array}{c}42 \\
(39 \%)\end{array}$ & $\begin{array}{c}49 \\
(49 \%)\end{array}$ \\
\hline
\end{tabular}

TABLE 12. Students' awareness of forms of education that, in accordance with new legal arrangements, should entitle nurses and midwives to prolong prescriptions for medication previously ordered by doctors.

Please indicate which of the following forms of education shall, in accordance with the new legal arrangements, entitle nurses and midwives to prolong prescriptions for medicines ordered earlier by doctors:
Question

\begin{tabular}{|c|c|c|c|c|}
\hline 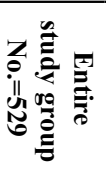 & 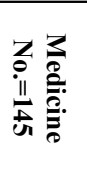 & 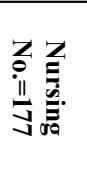 & 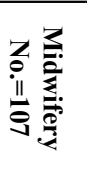 & 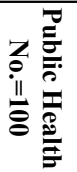 \\
\hline $\begin{array}{c}132 \\
(25 \%)\end{array}$ & $\begin{array}{c}20 \\
(14 \%)\end{array}$ & $\begin{array}{c}57 \\
(32 \%)\end{array}$ & $\begin{array}{c}28 \\
(26 \%)\end{array}$ & $\begin{array}{c}24 \\
(24 \%)\end{array}$ \\
\hline $\begin{array}{c}45 \\
(8 \%)\end{array}$ & $\begin{array}{c}8 \\
(6 \%)\end{array}$ & $\begin{array}{c}18 \\
(10 \%)\end{array}$ & $\begin{array}{c}14 \\
(13 \%)\end{array}$ & $\begin{array}{c}5 \\
(5 \%)\end{array}$ \\
\hline $\begin{array}{c}114 \\
(21 \%)\end{array}$ & $\begin{array}{c}23 \\
(16 \%)\end{array}$ & $\begin{array}{c}50 \\
(28 \%)\end{array}$ & $\begin{array}{c}23 \\
(21 \%)\end{array}$ & $\begin{array}{c}18 \\
(18 \%)\end{array}$ \\
\hline $\begin{array}{c}238 \\
(44 \%)\end{array}$ & $\begin{array}{c}92 \\
(63 \%)\end{array}$ & $\begin{array}{c}50 \\
(28 \%)\end{array}$ & $\begin{array}{c}41 \\
(38 \%)\end{array}$ & $\begin{array}{c}53 \\
(53 \%)\end{array}$ \\
\hline
\end{tabular}


TABLE 13. Students' knowledge of forms of education that, in accordance with new legal arrangements, shall entitle nurses and midwives to refer patients for selected diagnostic tests independently.

\begin{tabular}{|c|c|c|c|c|c|c|}
\hline & Question & 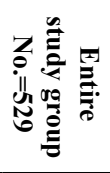 & 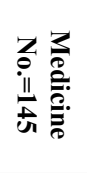 & 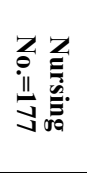 & 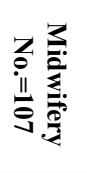 & 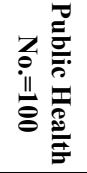 \\
\hline \multirow{4}{*}{$\begin{array}{l}\text { Please indicate which of the } \\
\text { following forms of education shall, } \\
\text { in accordance with the new legal } \\
\text { arrangements, entitle nurses } \\
\text { and midwives to refer patients } \\
\text { for selected diagnostic tests } \\
\text { independently? }\end{array}$} & $\begin{array}{l}\text { "specialization" and/or graduation from a Bachelor's } \\
\text { degree programme }\end{array}$ & $\begin{array}{c}156 \\
(29 \%)\end{array}$ & $\begin{array}{c}32 \\
(22 \%)\end{array}$ & $\begin{array}{c}61 \\
(34 \%)\end{array}$ & $\begin{array}{c}33 \\
(31 \%)\end{array}$ & $\begin{array}{c}28 \\
(28 \%)\end{array}$ \\
\hline & "specialization" & $\begin{array}{c}39 \\
(7 \%)\end{array}$ & $\begin{array}{c}5 \\
(3 \%)\end{array}$ & $\begin{array}{c}18 \\
(10 \%)\end{array}$ & $\begin{array}{c}11 \\
(10 \%)\end{array}$ & $\begin{array}{c}5 \\
(5 \%)\end{array}$ \\
\hline & Graduation from a Bachelor's degree programme & $\begin{array}{c}64 \\
(12 \%) \\
\end{array}$ & $\begin{array}{c}6 \\
(4 \%) \\
\end{array}$ & $\begin{array}{c}39 \\
(22 \%)\end{array}$ & $\begin{array}{c}12 \\
(11 \%)\end{array}$ & $\begin{array}{c}6 \\
(6 \%) \\
\end{array}$ \\
\hline & I do not know & $\begin{array}{c}270 \\
(50 \%)\end{array}$ & $\begin{array}{c}100 \\
(69 \%)\end{array}$ & $\begin{array}{c}59 \\
(33 \%)\end{array}$ & $\begin{array}{c}48 \\
(45 \%)\end{array}$ & $\begin{array}{c}61 \\
(61 \%)\end{array}$ \\
\hline
\end{tabular}

TABLE 14. Were the following questions concerning the knowledge of new professional competencies of nurses and midwives easy?

\begin{tabular}{lcccc}
\hline \hline \multirow{2}{*}{$\begin{array}{l}\text { Question } \\
\text { number }\end{array}$} & Nursing & Medicine & Midwifery & Public health \\
\cline { 2 - 5 } 1 & $0.53 / 0.53$ & $0.15 * / 0.15$ & $0.47 / 0.47$ & $040 / 0.40$ \\
\hline 2 & $0.42 / 0.42$ & $0.29 / 0.29$ & $0.21 / 0.21$ & $0.15 * / 0.15$ \\
\hline 3 & $0.71 / 0.71$ & $0.44 / 0.44$ & $0.43 / 0.43$ & $0.36 * / 0.36$ \\
\hline 4 & $0.22 / 0.22$ & $0.19 * / 0.19$ & $0.23 / 0.23$ & $0.24 / 0.24$ \\
\hline 5 & $0.32 / 0.32$ & $0.23 * / 0.23$ & $0.31 / 0.31$ & $0.27 / 0.27$ \\
\hline 6 & $0.06 / 0.06$ & $0.05 / 0.05$ & $0.04 * / 0.04$ & $0.05 / 0.05$ \\
\hline 7 & $0.64 / 0.64$ & $0.41 * / 0.41$ & $0.41 * / 0.41$ & $0.43 / 0.43$ \\
\hline 8 & $0.32 / 0.32$ & $0.22 / 0.22$ & $0.19 * / 0.19$ & $0.20 / 0.20$ \\
\hline 9 & $0.60 / 0.60$ & $0.44 * / 0.44$ & $0.45 / 0.45$ & $0.51 / 0.51$ \\
\hline 10 & $0.45 / 0.45$ & $0.19 * / 0.19$ & $0.22 / 0.22$ & $0.31 / 0.31$ \\
\hline 11 & $0.40 / 0.40$ & $0.23 * / 0.23$ & $0.24 / 0.24$ & $0.26 / 0.26$ \\
\hline 12 & $0.33 / 0.33$ & $0.14 * / 0.14$ & $0.26 / 0.26$ & $0.24 / 0.24$ \\
\hline 13 & $0.34 / 0.34$ & $0.22 * / 0.22$ & $0.32 / 0.32$ & $0.28 / 0.28$ \\
\hline
\end{tabular}

* the lowest easiness value for each question

TABLE 15. Sum of correct answers provided by students of different majors to questions about knowledge of new professional powers of nurses and midwives.

\begin{tabular}{|c|c|c|c|}
\hline \multirow[t]{2}{*}{ Major } & \multicolumn{3}{|c|}{$\begin{array}{l}\text { ANOVA range Kruskal-Wallis; } \mathrm{H}(3, \mathrm{~N}=478)=47.17747, \\
p<0.00001 / \\
\text { the Kruskal-Wallis ANOVA rank test; } \mathrm{H}(3, \mathrm{~N}=478)=47.17747, \\
\mathrm{p}<0.00001\end{array}$} \\
\hline & $\begin{array}{c}\text { Number of } \\
\text { correct answers } \\
\text { (No. of valid questions) }\end{array}$ & Sum of Ranks & Mean Rank \\
\hline Nursing & 158 & $46774.5 / 46774.5$ & $296.04 / 296.04$ \\
\hline Medicine & 126 & $23467.0 / 23467.0$ & $186.25 / 186.25$ \\
\hline Midwifery & 96 & $22242.0 / 22242.0$ & $231.69 / 231.69$ \\
\hline Public health & 98 & $21997.5 / 21997.5$ & $224.46 / 224.46$ \\
\hline
\end{tabular}

TABLE 16. Analysis of differences in level of students' knowledge (measured with the number of correct answers) between students of different majors.

\begin{tabular}{lcccc}
\hline \hline \multirow{2}{*}{ Major } & \multicolumn{5}{c}{$\begin{array}{c}\text { Post-hoc tests for multiple comparison } \\
\text { of mean rank sums for all subgroups }\end{array}$} \\
\cline { 2 - 5 } & $\begin{array}{c}\text { Nursing* } \\
\text { R:296.04 }\end{array}$ & $\begin{array}{c}\text { Medicine } \\
\text { R:186.25 }\end{array}$ & $\begin{array}{c}\text { Midwifery } \\
\text { R:231.69 }\end{array}$ & $\begin{array}{c}\text { Public health } \\
\text { R:224.46 }\end{array}$ \\
\hline Nursing & ------ & $<0.001 /<0.001$ & $0.002 / 0.002$ & $<0.001 /<0.001$ \\
\hline Medicine & $<0001 /<0.001$ & ----- & $0.091 / 0.091$ & $0.240 / 0.240$ \\
\hline Midwifery & $0002 / 0.002$ & $0.091 / 0.091$ & ------ & $1.000 / 1.000$ \\
\hline Public health & $<0.001 /<0.001$ & $0.240 / 0.240$ & $1.000 / 1.000$ & ------ \\
\hline
\end{tabular}

* Nursing students had significantly better results compared to any other major analysed here

\section{Limitations of the study results}

This is a pilot study due to the fact that another amendment of the legal provisions regulating the new competencies of nurses and midwives has been passed since the moment study was conducted. Some further research study needs to focus on the changes and has to be based on the most recent interpretation of the legal provisions in force in Poland expanding the powers of nurses and midwives to prescribe medicines, write out prescriptions, and refer patients for diagnostic tests.

\section{Direction for further research}

The authors believe that Pharmacy students should also be included in the study, since they are going to have similar professional competencies in the future.

\section{CONCLUSIONS}

1. The knowledge about extending professional competence of nurses and midwives among the study group of students of selected Polish universities was insufficient and needs to be urgently complemented.

2. Learning material needs to be modified not only for students of Nursing and Midwifery but also for other members of therapy team, e.g. physicians and pharmacists as well as specialists in public health.

\section{REFERENCES}

1. Ustawa $\mathrm{z}$ dnia 22 lipca 2014 r. o zmianie ustawy o zawodach pielęgniarki i położnej oraz niektórych innych ustaw. Dz. U. 2014, poz. 1136.

2. Ustawa $z$ dnia 11 września 2015 r. o zmianie ustawy o zawodach pielęgniarki i położnej oraz niektórych innych ustaw. Dz. U. 2015, poz. 1640.

3. Zakres praktyki, standardy i kompetencje pielęgniarki zaawansowanej praktyki. Seria regulacji prawnych Międzynarodowej Rady Pielęgniarek. Polskie Towarzystwo Pielęgniarskie 2010. Redakcja naukowa: Dorota Kilańska, Uniwersytet Medyczny w Łodzi. [http://www.ptp.na1.pl/pliki/ pdf/PTP_ICN_APN_2010.pdf]

4. Zarzeka A, Panczyk M, Belowska J, Gotlib J. Pielęgniarki i studenci pielęgniarstwa wobec rozszerzenia uprawnień zawodowych pielęgniarek i położnych w zakresie wystawiania recept oraz samodzielnego kierowania na badania diagnostyczne - sprawozdanie ze spotkania. Pielęg Pol. 2015;3(57):358-60.

5. Zarzeka A, Panczyk M, Ścieglińska B, et al. Postawy pielęgniarek oddziałowych wobec rozszerzenia uprawnień zawodowych w zakresie wystawiania recept oraz samodzielnego kierowania na badania diagnostyczne - wstępne badanie jakościowe. Pielęg Pol. 2015;4:409-14.

6. Zarzeka A, Gotlib J. \#Recepty\#Pielęgniarki\#Quo Vadis Rozszerzenie uprawnień zawodowych pielęgniarek i położnych w zakresie wystawiania recept oraz samodzielnego kierowania na badania diagnostyczne. Sprawozdanie z warsztatów „Roszczeniowy pacjent, czy błąd pielęgniarki? Odpowiedzialność prawna i zawodowa”. Med Dydakt Wychow. 2015;4:26-8 
7. Zarzeka A, Belowska J, Panczyk M, et al. Do nurses really need to know law? Perspectives of nurses on the eve of extending the scope of their competence in Poland. Abstractbook: Leiden International Medical Student Conference 11-15.03.2015.Wyd. S.E.M. Anema;2015. p. 308.

8. Zarzeka A, Panczyk M, Belowska J, et al. Recepty pielęgniarskie - wiedza i postawy pielęgniarek i położnych wobec rozszerzenia kompetencji zawodowych. Międzynarodowa Konferencja naukowo-szkoleniowa. „Innowacyjność w kształceniu, praktyce pielęgniarskiej i badaniach naukowych. 90-lecie powstania Uniwersyteckiej Szkoły Pielęgniarek i Opiekunek Zdrowia w Krakowie". 11-12 września 2015 r. Kraków.

9. Zarzeka A, Handzel S, Panczyk M, et al. Knowledge and attitudes of Medical University of Warsaw nursing students towards expanding professional competencies of nurses and midwifes. 2nd V4 Conference on Public Health 2015 Health for public, public for health. Zabrze, Polska.

10. Zarzeka A, Iwanow L, Pietruszewska K, et al Wiedza studentów Warszawskiego Uniwersytetu Medycznego na temat rozszerzenia kompetencji zawodowych pielęgniarek i położnych w zakresie ordynowania leków, wystawiania recept i kierowania na badania diagnostyczne. Med Probl. 2015;4.

11. Panczyk M, Zarzeka A, Iwanow L, et al. Ocena rzetelności i trafności autorskiego kwestionariusza do badania wiedzy i postaw wobec rozszerzenia uprawień zawodowych pielęgniarek i położnych w zakresie samodzielnego ordynowania niektórych leków, wystawiania recept oraz kierowania na wybrane badania diagnostyczne - doniesienie wstępne. Pielęg XXI w. $2016 ; 1$.

12. Opinia Komisji Bioetycznej Warszawskiego Uniwersytetu Medycznego [http://komisja-bioetyczna.wum.edu.pl/content/szczeg\%C3\%B3\%C5\% 82owe-informacje-oraz-wzory-dokument $\% \mathrm{C} 3 \% \mathrm{~B} 3 \mathrm{w}]$

13. Kroezen M, Francke AL, Groenewegen PP, van Dijk L. Nurse prescribing of medicines in Western European and Anglo-Saxon countries: a survey on forces, conditions and jurisdictional control. Int J Nurs Stud. 2012;49(8):1002-12.

14. Polczynski D, Oldenburg N, Buck M. The past, present and future of nurse prescribing in the United States. Nurs Prescribing. 2003;4(1):170-4.

15. Kroezen M, van Dijk L, Groenewegen PP, et al. Neutral to positive views on the consequences of nurse prescribing: Results of a national survey among registered nurses, nurse specialists and physicians. Int J Nurs Stud. 2014;51(4):539-48.
16. Romero-Collado A, Homs-Romero E, Zabaleta-del-Olmo E, Juvinya-Canal D. Nurse prescribing in primary care in Spain: legal framework, historical characteristics and relationship to perceived professional identity. J Nurs Manag. 2014;22(3):394-404.

17. Darvishpour A, Joolaee S, Cheraghi MA. A meta-synthesis study of literature review and systematic review published in nurse prescribing. MJIRI. 2014;28:77.

18. Gielen SC, Dekker J, Francke AL, et al. The effects of nurse prescribing: a systematic review. Int J Nurs Stud. 2014;51(7):1048-61.

19. Kroezen M, de Veer A, Francke A, et al. Changes in nurses' views and practices concerning nurse prescribing between 2006 and 2012: results from two national surveys. J Adv Nurs. 2014;70(11):2550-61.

20. Tokarski Ł. Nowelizacja ustawy o zawodach pielęgniarki i położnej Pielęgniarki mogą wypisywać recepty. Medexpress.pl. [http://www.medexpress.pl/start/nowelizacja-ustawy-o-zawodach-pielegniarki-i-poloznejpielegniarki-moga-wypisywac-recepty/61905/]

21. Kaczmarek A. Pielęgniarki i położne nie spieszą się do wypisywania recept. Rynek Zdrowia.pl [http://www.rynekzdrowia.pl/Polityka-zdrowotna/Pielegniarki-i-polozne-nie-spiesza-sie-do-wypisywania-recept,140393,14.html]

22. Medexpress.pl. Sondaż: czy lekarze chcą, żeby pielęgniarki wypisywały recepty? [http://www.medexpress.pl/start/sondaz-czy-lekarze-chca-zebypielegniarki-wypisywaly-recepty/62413/]

23. Serwis Zdrowie Wolters Kluwer. Od 1 stycznia 2016 pielęgniarki będą wypisywać recepty. [http://www.zdrowie.abc.com.pl/czytaj/-/artykul/od1-stycznia-2016-pielegniarki-beda-wypisywac-recepty]

24. Rynek Zdrowia.pl MZ: pielęgniarki i położne będa wystawiać recepty [http://www.rynekzdrowia.pl/Farmacja/MZ-pielegniarki-i-polozne-bedawystawiac-recepty, $152857,6 . \mathrm{html}]$

25. Serwis internetowy: prawalekarzy.pl Od kiedy i na jakie leki pielęgniarki i położne będą mogły wystawiać recepty? [http://prawalekarzy.pl/artykuly/ od-kiedy-i-na-jakie-leki-pielegniarki-i-polozne-beda-mogly-wystawiacrecepty-156]

26. Ministerstwo Zdrowia finalizuje prace nad projektem dot. nowych uprawnień. Portal internetowy Polskiego Towarzystwa Pielęgniarskiego. [http://www.ptp.na1.pl/index.php?option=com content\&task=view\&id=1 171\&Itemid=99999999]

27. Dziennik Wschodni. Rynek Seniora. Nowe kompetencje to dobre rozwiązanie dla pielęgniarek $\mathrm{z}$ opieki długoterminowej. [http://www. rynekseniora.pl/zdrowie/116/nowe kompetencje to dobre rozwiazanie dla_pielegniarek_z_opieki_dlugoterminowej,3500.html]

\section{Corresponding author}

Dr hab. n. o zdr. Joanna Gotlib,

Division of Teaching and Outcomes of Education, Faculty of Health Science, Medical University of Warsaw, Poland

61 Żwirki i Wigury Str., 02-091 Warszawa

tel. $(+48) 608108$ 028, fax: $(+48) 5720491$

E-mail: joanna.gotlib@wum.edu.pl 